\author{
Małgorzata Porąbaniec \\ Uniwersytet \\ Jana Kochanowskiego \\ w Kielcach
}

Eliminacja wykluczenia społecznego, red. M. Duda, K. Kutek-Sładek, Kraków 2017, s. 187-207 (Praca Socjalna w Teorii i Działaniu, 3).

DOI: http://dx.doi.org/10.15633/9788374385824.13

\title{
Działalność aktywizacyjna osób starszych w środowisku lokalnym
}

\author{
Activities activation of older people in the local community
}

\begin{abstract}
Ageing is a significant problem of the European community, which generates both new crises and challenges, but also goals to eliminate these crises or substantially reduce their impact on the population of seniors who need appropriate social support and financial security.
\end{abstract}

Therefore, different actions should be taken to fulfil the needs and desires of older people, and also to help them to stay as long as possible in their environment, enjoy life and undertaken activities.

Keywords: age, activating institutions, social work

Jedni są wiecznie młodzi, inni wiecznie starzy,

To kwestia charakteru, a nie kalendarzy...

J. Sztaudynger ${ }^{1}$

Obserwując dzisiejsze społeczeństwo, nawet z punktu widzenia zwykłego człowieka, można dostrzec, że samotność, szczególnie wśród osób starszych, stanowi ważną kwestię społeczną. Coraz więcej seniorów odczuwa samotność, często o podłożu psychicznym, które może prowadzić do wycofania się z codziennego życia i bierności społecznej, a w skrajnych przypadkach nawet do prób

1 J. Sztaudynger, [w:] Z. Szarota, Gerontologia społeczna i oświatowa, Zarys problematyki, Kraków 2004, s. 43. 
samobójczych. Poczucie osamotnienia to tylko jeden z wielu problemów, z jakimi boryka się ta grupa. Zaawansowany wiek niesie za sobą wiele niedogodności, takich jak choroby o podłożu biologicznym, demencje, wykluczenie ze środowiska społecznego czy trudności w wykonywaniu podstawowych życiowych czynności. Z tego względu należałoby podjąć działania zmierzające w kierunku zaspokojenia potrzeb i pragnień osób starszych, okazać większe zainteresowanie i wsparcie tej grupie społecznej. Przede wszystkim w dziedzinie aktywizacji seniorów, by mogli oni pozostać jak najdłużej w swoim środowisku, czerpiąc radość z życia i podejmowanych działań.

\section{Starzenie się społeczeństw jako ważny problem Europy}

Starzenie się ludności to ważna kwestia społeczna dotycząca nie tylko Polski czy Europy, ale i całego świata. Odniosę się tutaj do starzenia się populacji europejskich, uwzględniając fakt, jak Polska prezentuje się na tym tle.

Według informacji zawartych w periodyku „Pracownik Socjalny” obecnymi przyczynami starzenia się społeczności europejskich są:

- wydłużające się ludzkie życie,

- znaczne obniżenie liczby urodzeń,

- fakt, że do emerytalnego wieku zbliżają się członkowie pokolenia demograficznego wyżu po wojnie światowej,

- zmniejszenie umieralności.

W krajach Unii Europejskiej naturalny przyrost jest bliski zeru, a co piąty obywatel to emeryt. Kluczową rolę odgrywa więc polityka społeczna wobec ludzi starych stworzona przez Unię Europejską².

Tomasz Gabiś wskazuje ciekawą i niecodziennie podkreślaną tendencję, a mianowicie społeczeństwo europejskie niepokoi demograficzny kryzys. Według Gabisia ma on wymiar duchowy. Brak wiary w Europę oraz brak celu działania i dumy, do których możemy dołączyć roztrząsanie dawnych klęsk i zbrodni, stają się swoistą blokadą. Ważną drogą do pokonania kryzysu demograficznego jest przede wszystkim reorientacja, czyli zmiana tej mentalnej specyfiki europejskiej³.

2 Zob. W. Plitta, Polityka społeczna Unii Europejskiej wobec osób starszych, „Pracownik Socjalny" 10/2006, s. 8.

3 Zob. T. Gabiś, Od Unii Europejskiej do Imperium Europejskiego, [w:] Tożsamość Starego Kontynentu i przyszłość projektu europejskiego, pod red. D. Pietrzyk-Reeves, Warszawa 2007, s. 249. 
Pośrodku XX wieku w bogatej Europie oraz Ameryce znacznie rozprzestrzeniała się w obrębie społeczeństwa tak zwana,,rzeka starych”. Pod tym pojęciem kryje się największy wzrost liczby starych ludzi w historii świata. Jednak zjawisko to pojawiło się w nieodpowiednim momencie, ponieważ wtedy miała miejsce przemysłowa rewolucja, która była efektem otwartości i kreatywności pokoleń młodych. Osoby stare zostały zepchnięte na boczny tor, często z nieodpowiednią opieką lub całkowicie jej pozbawione ${ }^{4}$.

Jeżeli chodzi o sytuację Polski pod kątem starzenia się populacji, to stale podlega ona temu mechanizmowi, ponieważ liczba osób w wieku 60 lat i więcej ciągle wzrasta. Przełom 50. i 60. lat XX wieku był momentem, w którym postęp ludności polskiej kształtował się w dwóch orientacjach. Były to orientacje przeciwne. Z jednej strony wzrósł odsetek dzieci, a z drugiej zauważono także zwiększenie udziału seniorów w wieku 60 lat i więcej ${ }^{5}$. Był to skutek pojawienia się w latach powojennych fazy kompensacji. Wyż demograficzny wpłynął na spowolnienie procesu starzenia, nie likwidując go całkowicie. Warunkowały go zgony i nowe urodzenia. Później jednak odnotowano zmniejszenie liczby urodzeń. Miało to miejsce do roku 1969. Z kolei lata 80. XX wieku przyniosły nowy kierunek zmian i znów wzrosła liczba nowych urodzeń. Jednak wzrost ten nie była znaczący. Lata 90. to okres, kiedy w naszym kraju znacznie spadł wskaźnik liczby urodzeń. Ta tendencja utrzymała się do 2005 roku $^{6}$. Dwa lata później zanotowano wzrost liczby zgonów. Istotną kwestią jest fakt, że wraz ze starzeniem się populacji polskiej wskaźnik tych zgonów będzie ciągle rósł. Obniżenie liczby urodzeń wpłynęło na dynamikę przyrostu naturalnego, który miał tendencję ujemną ${ }^{7}$. Problem starzenia się Polski nas nie ominie. Jednak jeżeli będą do niej napływać rzesze imigrantów, to w 2100 roku będzie ona miała przeszło dwa razy mniej mieszkańców ${ }^{8}$. Jak wcześniej zaobserwowano, społeczeństwo całego świata demograficznie zwalnia. Kiedyś przypuszczano, że jego ludność osiągnie liczbę 12 mld. Jednak w kolejnych prognozach liczba ta ulegała zmianie. Z 12 mld zmniejszyła się do 10 mld. Nasz kraj zajmował 8 miejsce na kontynencie. Jednak bezustanne zmiany w tej sytuacji generują nowe spojrzenie na tę sprawę 9 .

Starzenie się to istotny problem europejskich społeczności, który generuje zarówno nowe kryzysy, jak i wyzwania i zadania mające te kryzysy eliminować

\footnotetext{
4 Zob. M. Oramus, B. Pietkiewicz, Siwe włosy ludzkości, „Polityka” 20/2001, s. 3-9.

5 Zob. Raport na temat sytuacji osób starszych w Polsce, oprac. P. Błędowski i in., Warszawa 2012, s. 23.

6 Zob. Raport na temat sytuacji osób starszych $w$ Polsce, dz. cyt., s. 24.

7 Zob. Raport na temat sytuacji osób starszych $w$ Polsce, dz. cyt., s. 24.

8 Zob. M. Rotkiewicz, Jesień świata, „Polityka” 20/ 2002, s. 76.

9 Zob. M. Henzler, Więcej dziadków niż wnuków, „Polityka” 49/2002, s. 20.
} 
bądź znacząco zmniejszać ich wpływ na populację seniorów, która potrzebuje odpowiedniego wsparcia społecznego oraz finansowego zabezpieczenia. Starzenie to problem, którego nie jesteśmy w stanie całkowicie wyeliminować i który będzie nieustannie towarzyszył kolejnym pokoleniom.

$\mathrm{W}$ poniżej zamieszczonej tabeli znajdują się dane wraz z prognozami dla krajów UE dotyczące średniej wieku w państwach europejskich.

Tabela 1. Średnia wieku w krajach UE z wyszczególnieniem Polski w latach 1980-2060.

\begin{tabular}{|l|c|c|c|c|c|c|c|c|c|}
\hline \multicolumn{1}{|c|}{ Rok } & 1980 & 1990 & 2000 & 2010 & 2020 & 2030 & 2040 & 2050 & 2060 \\
\hline Średnia UE & 32,4 & 34,5 & 37,1 & 39,8 & 42,2 & 44,4 & 46,3 & 46,8 & 47,2 \\
\hline Polska & 29,4 & 32,2 & 35,1 & 37,7 & 40,9 & 45,3 & 49,3 & 50,8 & 51,2 \\
\hline
\end{tabular}

Źródło: Opracowanie własne na podstawie: Departament tematyczny. Spójność spoteczna i rozwój demograficzny w zrównoważonej Europie, Parlament Europejski, Bruksela 2011, s. 11.

Średnia wieku ma tendencję wzrostową. Widzimy, że na przestrzeni lat regularnie wzrasta odsetek średniej wieku w UE. Co istotne, w 2060 roku odsetek ten wyniesie niemalże 50 proc. Jest to niepokojąca tendencja, która dość dobrze odzwierciedla proces starzenia się społeczeństw europejskich. Polska na tym tle również wykazuje tendencję wzrostową.

Tabela 2. Procent populacji 65 lat i więcej w krajach UE wraz z Polską

\begin{tabular}{|l|c|c|c|c|c|c|c|c|c|}
\hline \multicolumn{1}{|c|}{ Rok } & 1980 & 1990 & 2000 & 2010 & 2020 & 2030 & 2040 & 2050 & 2060 \\
\hline Średnia UE & 12,5 & 12,9 & 14,5 & 16,0 & 19,1 & 22,6 & 25,6 & 27,8 & 29,3 \\
\hline Polska & 10,2 & 10,0 & 12,1 & 13,5 & 17,9 & 22,5 & 25,1 & 30,3 & 34,5 \\
\hline
\end{tabular}

Źródło: Opracowanie własne na podstawie: Departament tematyczny. Spójność społeczna i rozwój demograficzny w zrównoważonej Europie, Parlament Europejski, Bruksela, 2011, s. 12.

Jak obrazuje powyższa tabela, procent osób w wieku 65 lat i więcej w kolejnych latach sukcesywnie wzrasta. Ciekawe jest, że w UE w latach 2010-2020 liczba ta wzrosła aż o 3 proc. i w kolejnych latach według prognoz nadal będzie 
wzrastać. Na lata 2040-2060 przewidywany jest największy przyrost populacji seniorów. W Polsce zależności procentowe między kolejnymi latami również wzrastają systematycznie, przy czym największy przyrost procentowy będzie zauważalny w latach 2040-2050.

Tabela 3. Procent populacji w wieku 80 lat i więcej w krajach UE z Polską

\begin{tabular}{|l|c|c|c|c|c|c|c|c|c|}
\hline \multicolumn{1}{|c|}{ Rok } & 1980 & 1990 & 2000 & 2010 & 2020 & 2030 & 2040 & 2050 & 2060 \\
\hline Średnia UE & 2,1 & 2,8 & 3,0 & 4,1 & 5,0 & 6,5 & 8,4 & 10,1 & 11,5 \\
\hline Polska & 1,4 & 2,0 & 1,9 & 3,3 & 4,3 & 5,5 & 9,1 & 9,6 & 12,3 \\
\hline
\end{tabular}

Źródło: Opracowanie własne na podstawie: Departament tematyczny. Spójność społeczna i rozwój demograficzny w zrównoważonej Europie, Parlament Europejski, Bruksela, 2011, s. 13.

Procent zbiorowości państw europejskich w wieku 80 lat i powyżej również ma tendencję wzrostową. Oznacza to, iż ludności w tym wieku wraz z kolejnymi latami także będzie przybywać. Bazując na powyższych tabelach, można stwierdzić, że największy przyrost ludności senioralnej będzie miał miejsce w latach dwudziestych tego wieku.

\section{Konsekwencje procesu starzenia się i starości}

Jeżeli zatem dzieciństwo i młodość są czasem, w którym człowiek stopniowo uczy się swojego człowieczeństwa, rozpoznaje swoje możliwości, poniekąd tworzy projekt życia, który będzie realizował w wieku dojrzałym, to i starość nie jest pozbawiona szczególnej wartości, ponieważ - jak zauważa św. Hieronim - łagodząc namiętności „pomnaża mądrość i służy dojrzalszymi radami”. W pewnym sensie jest to czas szczególnie nacechowany mądrością, którą zwykle przynoszą z sobą lata doświadczeń, jako że „czas jest znakomitym nauczycielem"10.

Konsekwencje procesu starzenia się mają wielopłaszczyznowy charakter. Najważniejsze następstwa przejawiają się w zakresie ekonomii, opieki zdrowotnej, relacji międzypokoleniowych w społeczeństwie oraz rodzinie.

\footnotetext{
10 Jan Paweł II, List Do moich braci i sióstr - ludzi w podeszłym wieku.
} 
Na płaszczyźnie ekonomii fundamentalnym problemem staje się liczba ludności w wieku produkcyjnym wciąż rosnąca w stosunku do liczby osób w wieku poprodukcyjnym, a zatem zmieniający się stosunek aktywnych zawodowo do osób pobierających świadczenia emerytalne i rentowe. Aby zobrazować ową relację, należy posłużyć się współczynnikiem obciążenia ekonomicznego, który określa zależności pomiędzy ludnością w wieku poprodukcyjnym (kobiety 60 lat i więcej, mężczyźni - 65 lat i więcej) oraz ludnością w wieku produkcyjnym (kobiety - 18-59 lat, mężczyźni - 18-64 lata). Według przeprowadzonych badań w Polsce pomiędzy 2007 a 2035 rokiem stosunek ten ma ulec podwyższeniu o prawie połowę: z przypadających na 100 osób w wieku produkcyjnym w 2007 roku 24,8 osób w wieku poprodukcyjnym na 46,4 w roku 2035. Oznacza to, że aby zachować wysokość świadczeń emerytalno-rentowych, a także standardy opieki zdrowotnej osób starszych, konieczne jest zwiększenie obciążeń fiskalnych nakładanych na wynagrodzenia oraz wydatki ponoszone w głównej mierze przez ludzi aktywnych zawodowo, czyli młodych ${ }^{11}$.

$\mathrm{W}$ aspekcie zdrowotnym w wyniku postępującego procesu starzenia się ludności pojawiają się nowe zadania i cele: wzrastają wydatki na służbę zdrowia, jak również zapotrzebowanie na usługi dotyczące specyficznych potrzeb pacjentów seniorów. Zapotrzebowanie na opiekę nad osobami starszymi będzie wynikać nie tylko ze wskaźnika demograficznego, ale również z przemian mentalnych. Wzrost odsetka osób w wieku emerytalnym stanowi też wyzwanie dla polityki socjalnej państwa, pojawiła się bowiem potrzeba budowania specjalnych programów gwarantujących dostęp do specjalistycznych usług socjalnych i zdrowotnych, sprzyjających zdrowemu starzeniu się. Wzrośnie też zapotrzebowanie na lekarzy geriatrów. Dziś jest ich w Polsce około 300, co w proporcji do liczby ludności stanowi około jednej czwartej średniej europejskiej. Dlatego bardzo pilną potrzebą jest rozwinięcie sieci oddziałów opieki geriatrycznej i paliatywnej oraz budowanie nowych i unowocześnianie działających już hospicjów. Powinny wzrosnąć również wydatki na rehabilitację oraz działania prewencyjne, mające na celu zmniejszenie prawdopodobieństwa wystąpienia niektórych schorzeń i niepełnosprawności. Pierwszoplanową instytucją opiekuńczą jest tradycyjnie rodzina. Jednakże narastające w ostatnich latach zmiany w strukturze i charakterze współczesnej rodziny (niski poziom urodzeń, życie w wolnych związkach, coraz liczniejsza grupa tych, którzy nie mają potomstwa) powodują, że rodzina w swoich funkcjach opiekuńczych przestaje być wydolna. Emigracja zarobkowa ludzi młodych sprawia, że wiele osób starszych pozostaje bez opieki. Problemy opieki nad osobami niezdolnymi

11 Zob. P. Szukalski, Starzenie się ludności - wyzwanie XXI wieku, [w:] Przygotowanie do starości. Polacy wobec starzenia się, pod red. P. Szukalskiego, Warszawa 2009, s. 13. 
do samodzielnej egzystencji w wyniku zmian demograficznych i społecznych wraz z upływem czasu będą się nasilały. Coraz pilniejsza staje się też kwestia wprowadzenia w Polsce (funkcjonującego już w niektórych krajach Unii Europejskiej) obowiązkowego ubezpieczenia pielęgnacyjnego ${ }^{12}$. Wobec zmniejszającej się roli rodziny jako podstawowej instytucji świadczącej wsparcie i usługi opiekuńcze wzrastająca liczba seniorów wymaga zwrócenia uwagi na problem dostępności i skuteczności istniejących programów i narzędzi służących włączaniu osób starszych w życie zawodowe i publiczne (w celu przeciwdziałaniu wykluczeniu społecznemu seniorów).

W obszarze pomocy społecznej niezbędne jest stworzenie sieci pomocy środowiskowej, która będzie odpowiedzią na lokalne zapotrzebowanie na pomoc udzielaną w miejscu zamieszkania osoby starszej. Bardzo zróżnicowana oferta usług dla osób starszych na wszystkich szczeblach samorządu wynika z różnego zaangażowania w wykorzystywanie możliwości, jaka dają zapisy Ustawy z dnia 12 marca 2004 r. o pomocy społecznej ${ }^{13}$. Powinna poszerzyć się również rola pracowników socjalnych jako osób pozostających w bezpośredniej interakcji z seniorem i znających jego potrzeby. Przewiduje się wprowadzenie obowiązkowego pakietu usług pomocy i integracji społecznej dla osób starszych, obejmującego głównie:

- pracę socjalną (mającą na celu poprawę sytuacji życiowej osób starszych i ich rodzin),

- interwencję kryzysową (sprowadzającą się do poradnictwa prawnego, zapewnienia schronienia, poradnictwa socjalnego, umożliwienia udziału w grupach wsparcia),

- usługi mieszkaniowe (mieszkania chronione i adaptacyjne, likwidacja barier architektonicznych),

- usługi żywieniowe (zróżnicowana oferta zapewnienia posiłków lub produktów żywnościowych, dostarczanie produktów żywnościowych do miejsca zamieszkania, rozszerzenie sieci tanich stołówek i jadłodajni),

- usługi opiekuńcze świadczone w miejscu zamieszkania (umożliwienie zaspokojenia niezbędnych potrzeb życiowych),

12 „Problemów osób niesamodzielnych nie rozwiąże [...] działalność pomocy społecznej ani organizacji pozarządowych. Nie rozwiąże ich także wolny rynek usług. Większość osób niezdolnych do samodzielnej egzystencji nie ma bowiem środków na zakup usług na wolnym rynku. Rozwiązanie tego problemu musi nastąpić w ramach systemu zabezpieczenia społecznego. Jednak w istniejącym obecnie systemie, niezdolność do samodzielnej egzystencji nie jest objęta ubezpieczeniem”. Ubezpieczenie pielęgnacyjne jako propozycja rozwiązań, www.czytelniamedyczna.pl (dostęp: 20.02.2016).

13 Ustawa z dnia 14 marca 2004 r. o pomocy społecznej, Dz.U. 2004 nr 64 poz. 593. 
- usługi opiekuńcze realizowane w ośrodkach wsparcia dziennego (realizowane w dziennych domach pomocy dla osób starszych i wyspecjalizowanych w odpowiednich schorzeniach, np. choroba Alzheimera, Parkinsona),

- usługi opiekuńcze świadczone w całodobowych formach opieki (zróżnicowana oferta o charakterze pielęgnacyjno-opiekuńczym realizowana jako świadczenia pomocy społecznej udzielane w: całodobowych ośrodkach wsparcia w rozumieniu ustawy o pomocy społecznej, tj. schroniskach, domach dla bezdomnych, mieszkaniach chronionych, rodzinnych domach pomocy, domach pomocy społecznej),

- usługi wspomagające - w tym poradnictwo specjalistyczne (rozwiązywanie problemów życiowych osób starszych i ich rodzin),

- usługi wspomagające - w tym lecznicze i rehabilitacyjne (zróżnicowana oferta umożliwiająca utrzymanie bądź polepszenie ogólnego stanu psychofizycznego realizowana jako: zapewnienie dostępu do usług geriatrycznych, zapewnienie dostępu do rehabilitacji zdrowotnej, świadczenie usług rehabilitacyjnych, wypożyczanie sprzętu rehabilitacyjnego, przedmiotów ortopedycznych i środków pomocniczych, zajęcia usprawniające, np. rekreacyjno-sportowe),

- integracja międzypokoleniowa (działania wspierające tworzenie trwałych więzi pomiędzy grupami zróżnicowanymi ze względu na wiek, m.in. przez zapewnienie udziału w integracyjnych przedsięwzięciach) ${ }^{14}$.

W dziedzinie instytucjonalnej pomocy społecznej potrzebna będzie rozbudowa sieci domów pomocy społecznej. Zarówno domy dla osób w podeszłym wieku, jak i domy dla osób somatycznie chorych będą musiały przygotować się na przyjęcie większej liczby mieszkańców. Już obecnie w domach pomocy społecznej obserwuje się zwiększanie liczby mieszkańców w wieku 75 lat i więcej, a stan zdrowia osób w tej grupie wieku jest gorszy niż osób w wieku 60-74 lata. Przemiany społeczne spowodują konieczność poszerzenia oferty w zakresie domów pomocy dla osób starszych. Wzrost zamożności społeczeństwa będzie skutkował zwiększeniem wymagań wobec standardu zamieszkiwania w różnych ośrodkach wsparcia dla osób starszych.

14 Zob. K. Balon i in., Preambuła i pakiet usług pomocy i integracji społecznej dla osób starszych, Projekt 1.18 „Tworzenie i rozwijanie standardów usług pomocy i integracji społecznej” współfinansowany ze środków Unii Europejskiej w ramach Europejskiego Funduszu Społecznego, Warszawa 2014, s. 14-20. 


\section{Społeczne skutki starzenia się i starości}

Problemy osób starszych można przypisać do jednej z dwóch kategorii: wynikające ze schorzeń psychosomatycznych oraz będące efektem ich funkcjonowania w środowisku społecznym. Problemy prowadzą do marginalizacji, a także ekskluzji społecznej tej kategorii, powodując pogłębianie doświadczanych trudności z powodu poczucia bezużyteczności, osamotnienia, ubóstwa i niepełnosprawności ${ }^{15}$. Wymienię tu choćby:

Samotność i osamotnienie. „Problem samotności może być odczuwany z różną intensywnością przez osoby w starszym wieku. Przyjmuje on najtrudniejszą formę w sytuacji śmierci współmałżonka. Częściej doświadczają go kobiety niż mężczyźni. Z racji dłuższego czasu życia kobiet trzykrotnie częściej zostają one wdowami niż mężczyźni wdowcami. Poza tym, z tych samych powodów (duża liczba kobiet w starszym wieku i jednocześnie mała liczba mężczyzn), a także większej akceptacji społecznej, mężczyźni powtórnie żenią się, a więc nie są już samotni” ${ }^{16}$. Związki z rodziną dają większą satysfakcje kobietom niż mężczyznom. Należy jednak zaznaczyć, że mężczyźni odczuwają samotność $\mathrm{w}$ innym aspekcie. Kobiety znacznie łatwiej utrzymują kontakty przyjacielskie i towarzyskie, natomiast mężczyźni mają z tym więcej problemów. Ich znajomości związane są przede wszystkim z miejscem pracy. Po przejściu na emeryturę trudno jest im utrzymać te znajomości, jak również nawiązać nowe. W eliminacji tego problemu dużą rolę mogą odgrywać grupy samopomocowe dla osób starszych, których przykładem mogą być kluby seniora albo uniwersytety trzeciego wieku' ${ }^{17}$.

Seniorzy bardzo często pomimo mnóstwa ludzi wokół siebie czują się samotni i są osamotnieni w swoich potrzebach i pragnieniach. Można to tłumaczyć tym, że młodzi ludzie nie zawsze potrafią czy nawet nie chcą próbować zrozumieć człowieka w starszym wieku. Rodzina nie zawsze może zaspokoić niezwykle ważną potrzebę kontaktu z innymi osobami i przynależności do jakiejś grupy. Ludzie starsi potrzebują szczególnie kontaktu i rozmowy z osobami w podobnym wieku. Wiąże się to $\mathrm{z}$ tym, że mają oni wspólne wspomnienia związane na przykład z latami młodzieńczymi. Łączą ich także wspólne problemy, które w grupie łatwiej rozwiązać, czy chociażby pasje, które mogą razem rozwijać.

15 Zob. M. Porąbaniec, Instytucjonalny wymiar pracy socjalnej na rzecz osób starszych $w$ środowisku lokalnym, [w:] Człowiek stary $w$ rodzinie i społeczeństwie, red. A. Kotlarska-Michalska, Poznań 2013, s. 191.

16 Zob. S. Kowalik, Pedagogiczne problemy funkcjonowania i opieki osób w starszym wieku, [w:] Pedagogika specjalna, red. W. Dykcik, Poznań 2001, s. 211.

17 Zob. S. Kowalik, Pedagogiczne problemy funkcjonowania..., dz. cyt., s. 211. 
Dolegliwości i choroby - pogarszający się stan zdrowia można uznać za zjawisko typowe dla osób w starszym wieku. Według szacunków amerykańskich aż 86 proc. osób powyżej 65. roku życia cierpi na jakąś chorobę przewlekłą. Choroby te można podzielić na somatyczne i psychiczne. Większość chorób somatycznych wiąże się z chronicznymi bólami, które wpływają w znacznym stopniu na ograniczenie aktywności życiowej seniorów. Powoduje to konieczność odpowiedniej pielęgnacji w domu, a nawet okresowej hospitalizacji. Odpowiednia opieka lekarska i rehabilitacja mogą znacznie ograniczyć dolegliwości spowodowane przez choroby ${ }^{18}$. Edgar Miller i Robin Morris uważają, że u osób w starszym wieku z powodu organicznych uszkodzeń mózgu pojawiają się m.in. choroba Alzheimera, choroba Parkinsona, stwardnienie rozsiane. „Wszystkie te schorzenia mogą doprowadzić do takiej degradacji psychicznej, że musi być sprawowany nad tymi pacjentami ciągły nadzór. W wyniku wystąpienia tych chorób dochodzi do stopniowo nasilającej się demencji: zaniku pamięci, utraty świadomości miejsca i czasu, trudności w posługiwaniu się językiem, labilności emocjonalnej, braku motywacji do jakiegokolwiek działania itd. Szacuje się, że osób z zaawansowanymi zmianami dementywnymi w przedziale wiekowym 65-69 lat jest 2,1\%. Odpowiednio dla osób w wieku 70-74 lata wartość ta wynosi 3,3\%, dla wieku 75-79 lat wynosi 8,0\% i dla osób powyżej 80 lat wynosi aż 17,7\%"19. Nikt nie lubi być sam, każdy boi się samotności, a gdy jeszcze dochodzi do tego choroba, to sytuacja staje się bardzo trudna. W takim przypadku szczególnie ważne dla osób starszych jest wsparcie bliskich. Dzięki temu osoby chore łatwiej znoszą tę sytuacje i mają siłę do walki z chorobą.

Syndrom pustego gniazda to „kryzys emocjonalny, jaki dotyka rodziców po opuszczeniu domu przez ich dorosłe dzieci. Jako młodsi rodzice, przytłoczeni obowiązkami wychowawczymi, zwykle wiążemy ten czas z odzyskaniem upragnionej wolności, traktujemy jak okazję do realizacji dawno odkładanych planów. Kiedy jednak odejście dzieci staje się faktem, zamiast ulgi pojawia się uczucie pustki i osamotnienia. Okazuje się, że nie ma czym wypełnić powstałej luki, a więź z partnerem, do tej pory oparta głównie na wspólnej opiece nad potomstwem, stopniowo się rozluźnia”20.

Lęk przed śmiercią - jest problemem wymagającym szczególnej delikatności. Jest jednym z najbardziej pierwotnych przeżyć w świecie ożywionym. U człowieka nabiera on szczególnego znaczenia, gdyż opiera się nie na rzeczywistym przeżyciu własnej śmierci, lecz na antycypacji prawdopodobieństwa

18 Zob. S. Kowalik, Pedagogiczne problemy funkcjonowania..., dz. cyt., s. 213.

19 Zob. S. Kowalik, Pedagogiczne problemy funkcjonowania..., dz. cyt., s. 213.

20 Syndrom pustego gniazda - jak sobie $z$ nim radzić?, www.poradnikzdrowie.pl (dostęp: 20.02.2016). 
jej nastąpienia. Jednymi z zasadniczych cech lęku przed śmiercią są jego powszechność i nieuchronność. Jeszcze innym źródłem lęku przed śmiercią jest perspektywa osamotnienia. Dotyczy to szczególnie tych sytuacji, kiedy stajemy w obliczu - mniej lub bardziej realnej - możliwości utraty bliskiej osoby. Ten interpersonalny aspekt osamotnienia przejawia się głównie w postaci obaw o losy przyjaciół i rodziny. Poczucie osamotnienia wynikające z zerwania więzi z własnymi korzeniami (aspekt społeczny) także może sprzyjać nasilaniu się lęku tanatycznego, gdyż wiąże się z przemyśleniami na temat niepewności co do naszego przyszłego życia ${ }^{21}$. Dla ludzi w starszym wieku sama perspektywa zbliżającego się kresu życia zawiera element zagrożenia, z którym koniecznie trzeba sobie poradzić. Zagrożone mogą być wartości, które mają bardzo duże znaczenie dla funkcjonowania jednostki, nie tylko życie w sensie fizycznym, ale także psychicznym²

W takim razie jak radzić sobie z lękiem przed śmiercią? Czy możemy go zagłuszyć? Ostatnie badania pokazują, że świadomość śmierci pełni również pozytywną funkcję. Świadomość własnej śmiertelności zwiększa chęć pomagania innym, wpływa na potrzebę dbania o własne zdrowie, a także może stać się motywacją do lepszego wykorzystania życia ${ }^{23}$.

\section{Rola instyłucji w aktywizowaniu osób starszych}

Jesień życia nie musi oznaczać całkowitego wycofania się z tego, co daje radość i nadzieję. W XXI wieku, w dobie postępu cywilizacyjnego i technologicznego, w zawrotnym tempie pojawiają się także możliwości dla osób w podeszłym wieku. Oprócz wypełniania zadań rozwojowych, bycia babcią czy dziadkiem ludzie starsi mogą rozwijać własne pasje, zainteresowania oraz nabywać nowe umiejętności, zawierać znajomości i spełniać swe marzenia. Aktywni seniorzy dzięki instytucjom do tego stworzonym i wolnemu czasowi mają szansę przeżyć swoją drugą młodość. Obecnie tworzy się coraz więcej miejsc i placówek, które chcą aktywizować seniorów poprzez szeroką gamę zajęć, szkoleń i wycieczek.

21 Zob. J. Jastrzębski, Psychologiczny wymiar lęku przed śmiercia, www.psychologia. net.pl (dostęp: 20.02.2016).

22 Zob. I. Pufal-Struzik, Poczucie osamotnienia i lęku u ludzi starszych, [w:] Trzeci wiek bez starości, red. A. Jopkiewicz, E. Trafiałek, Kielce 2000, s. 89.

23 Problematyka cierpienia i śmierci poruszana jest bardzo często na portalach internetowych, gdzie ludzie dzielą się swoimi przemyśleniami i wątpliwościami natury filozoficznej, religijnej, biologicznej i społecznej. Np. Obsesyjny lęk przed śmiercią, www.netkobiety.pl, Paniczny lęk przed śmiercia, www.psychiatria.pl, Paniczny strach przed śmiercia a nerwica, www. forum.kardiolo.pl (dostęp: 20.02.2016). 


\subsection{Uniwersytety trzeciego wieku}

Uniwersytet jest placówką oświatową przeznaczoną dla osób starszych. Główne jego zadaniem polega na polepszeniu jakości życia seniorów ${ }^{24}$. Występują dwa typy uniwersytetu trzeciego wieku:

- Model brytyjski, który bazuje na samorealizacji i wzajemnej pomocy ludzi w podeszłym wieku bez udziału uczelni wyższych ${ }^{25}$.

- Model francuski prowadzi ścisłą kooperację ze środowiskiem uniwersyteckim. Nacisk kładziony jest na wysoki standard ofert dydaktycznych oraz prac badawczo-naukowych. Jego struktura może być dwojaka - całkowita konsolidacja z uczelnią bądź kompletna niezależnośćc6.

Uniwersytety trzeciego wieku (UTW) to placówki dydaktyczne. Zakres jego działania oraz programy dydaktyczne opracowywane są na podstawie współpracy ze słuchaczami uniwersytetu. Placówka stwarza możliwość nawiązywania nowych, satysfakcjonujących kontaktów, pomaga w przygotowaniu do starości, rozwija talenty i zainteresowania, pobudza do aktywności. Głównym celem uniwersytetów jest poprawa jakości życia seniorów przez włączenie do systemu kształcenia ustawicznego, utrzymanie sprawności intelektualnej, psychicznej oraz fizycznej ${ }^{27}$. „Ważnymi celami działania UTW są również aktywizacja i integracja osób starszych oraz włączanie ich w życie publiczne i obywatelskie społeczności lokalnych jako pełnoprawnych członków społeczeństwa obywatelskiego. Niezwykle ważną rolą UTW jest integracja międzypokoleniowa oparta na inicjowaniu współpracy w szczególności ze szkołami wyższymi, dzięki czemu w uniwersytetach trzeciego wieku mogą odbywać się studenckie praktyki i staże zawodowe, podczas których studenci prowadzą m.in.: kursy komputerowe, językowe, zajęcia ruchowe i inne"28.

Uniwersytety trzeciego wieku mają wpłynąć na poprawę jakości życia osób starszych. Zadaniem ich jest pobudzanie do szeroko rozumianej aktywności, motywowanie do działania, integracja, przygotowanie do okresu starości. Mają zapobiegać osamotnieniu oraz wykluczeniu osób starszych z życia społecznego. Uczestnictwo w życiu uniwersyteckim ma wpłynąć na pomyślne starzenie

24 Zob. K. Kurowska, Aktywizacja osób w starszym wieku w aspekcie działalności Uniwersytetów Trzeciego Wieku oraz innych instytucji i organizacji pozarządowych, [w:] Kompendium pielegnowania..., dz. cyt., s. 51.

25 Zob. A. Matalkiewicz, Edukacja seniorów w Wielkiej Brytanii - Uniwersytet Trzeciego Wieku, „Edukacja Dorosłych” 2 (2003), s. 125.

26 Zob. J. Halicki, Edukacja seniorów w aspekcie teorii kompetencyjnej. Studium historyczno-porównawcze, Białystok 2000, s. 38-42.

27 Zob. Z. Sztajer, Idea powstania i działalność uniwersytetów trzeciego wieku, www. edukator.koweziu.edu.pl/176/ (dostęp: 19.11.2015).

28 D. Jachimowicz, W. Nalepa, Tworzenie Uniwersytetu Trzeciego Wieku - krok po kroku, Nowy Sącz 2012, s. 10. 
oparte na zasadach godności życia człowieka. Edukacja seniorów nakierowana ma być na rozwój kompetencji zawodowych, a jej celem jest zdobycie wiedzy oraz umiejętności, które zapewnia samodzielność, samowystarczalność osób starszych oraz aktywność społeczną.

\subsection{Domy opieki rodzinnej}

Są to placówki prywatne, w których pensjonariusze sami opłacają swój pobyt. Oferują pobyt stały oraz pobyt krótkoterminowy ograniczony czasowo do jednego miesiąca. W ramach opłaty placówka udostępnia pensjonariuszowi pokój mieszkalny z łazienką łazienką i toaletą, wyposażony w meble i podstawowy sprzęt. Ponadto zapewnia wyżywienie, podstawowe środki higieny osobistej i środki czystości, całodobową opiekę. Daje możliwość kontaktu z lekarzem rodzinnym oraz udziału w różnego rodzaju imprezach o charakterze kulturalno-oświatowym. Świadczeniodawca jest również zobowiązany do sprzątania pomieszczenia pensjonariusza nie rzadziej niż raz dziennie, prania odzieży, bielizny oraz pościeli, organizowania zajęć rehabilitacyjnych i terapeutycznych, uwzględniając poziom sprawności fizycznej i intelektualnej danej osoby oraz dostarczania podstawowych środków farmakologicznych.

Formy aktywizacji pensjonariuszy:

Terapia zajęciowa - są to przede wszystkim zajęcia manualne przy użyciu takich materiałów jak np. bibuła, plastelina, modelina, masa solna; zajęcia plastyczne typu wycinanki, wydzieranki, wyklejanki, mogą to być także gry planszowe i zabawy stolikowe. Ciekawym zajęciem jest ikebana, czyli układanie bukietów z kwiatów, czy też makrama - stara sztuka wiązania sznurków bez użycia igieł czy drutów, np. w bransoletki z muliny. Na powietrzu organizowane są zajęcia rekreacyjne z wykorzystaniem piłki, małych piłeczek, paletek, czasem jest to też minigimnastyka, słuchanie muzyki - muzykoterapia. Niezwykle powszechnym zajęciem dla starszych ludzi jest uprawa i pielęgnowanie działki. W domach jest taka możliwość - na terenie obiektu znajdują się działki ogrodnicze do wykorzystania przez pensjonariuszy według własnych upodobań, mają więc oni własny ogródek, o który sami dbają, pielęgnują kwiaty, sieją warzywa itp.

Rozwijanie potrzeb i zainteresowań kulturalnych pensjonariuszy - domy zapewniają rozwijanie i krzewienie zainteresowań pensjonariuszy o charakterze kulturalnym. Ważne jest kultywowanie i podtrzymywanie tradycji, szczególnie widocznych w czasie świąt Bożego Narodzenia oraz Wielkanocy. W ramach przygotowań świątecznych podopieczni gromadzą się w ogrodzie zimowym lub świetlicy i zajmują się przygotowywaniem koszyczków z wielkanocną święconką, malują pisanki, wspominają poprzednio spędzone święta i dyskutują o tradycjach wielkanocnych. W dni świąteczne również zachowuje się tradycję: 
pensjonariusze święcą pokarmy, dzielą się jajkiem, spożywają wielkanocne śniadanie. Odrębną formą terapeutyczną są wyjazdy na turnusy rehabilitacyjne, wycieczki krajoznawcze i rekreacyjne.

Udział w imprezach i uroczystościach - oprócz Dnia Babci czy Dziadka, Dnia Seniora, organizuje się także Dzień Kobiet, kiedy to wszystkie panie dostają kwiaty od swoich rówieśników - pensjonariuszy. Opiekunowie nie zapominają również o imieninach i urodzinach swoich podopiecznych. Gdy któryś z mieszkańców obchodzi okrągłe urodziny, np. 80, 85 czy 90, dostaje dyplom z gratulacjami, życzeniami, w stołówce podawany jest poczęstunek. Działania tego typu znacznie podnoszą samoocenę i poczucie własnej wartości osób w podeszłym wieku. Organizowane są mikołajki, walentynki, zabawy karnawałowe, andrzejkowe, pensjonariusze uczestniczą również w różnych festynach, odpustach, koncertach, festiwalach. Dobrze rozwinięta jest współpraca z kieleckim uniwersytetem trzeciego wieku oraz klubami seniora $\mathrm{z}$ całego województwa. Mieszkańcy spotykają się z członkami tych klubów, rozmawiają, dyskutują, wymieniają się poglądami, jest to ważne, ponieważ spotykają się z ludźmi innymi niż spotykani na co dzień współmieszkańcy i opiekunowie placówki.

\subsection{Kluby seniora}

Mają one charakter bardziej lokalny, są „nastawione na twórcze i wartościowe spędzanie czasu wolnego" ${ }^{29}$. Ich celem jest umożliwienie ludziom starszym przyjemnego, twórczego spędzenia czasu wolnego, stworzenie możliwości zaspokojenia różnorodnych potrzeb: wypoczynku, aktywności, potrzeb kulturalno-oświatowych, a także budzenie nowych zainteresowań ${ }^{30}$. Działania klubów polegają na propagowaniu i organizowaniu rozmaitych form aktywności fizycznej, społecznej i kulturalnej, spędzania wolnego czasu, prowadzenia zajęć z grupami zróżnicowanymi ze względu na wiek, stan zdrowia, sprawność fizyczną czy wykształcenie, formowania postaw i wartości prospołecznych, moralnych i kulturalnych. Uczestnicy klubu samorządnie decydują o rodzajach swojej pracy, ustalają razem terminy spotkań, kogo zaprosić, organizują imprezy. Są oni zazwyczaj bardzo związani z klubem. Koordynatorem klubu jest kierownik ${ }^{31}$.

Osoby starsze chcą aktywnie spędzać czas, a nie siedzieć w domach. Zainteresowanie najróżniejszymi zajęciami jest ogromne i rośnie z roku na rok. Najwięcej chętnych jest wśród kobiet, ale też coraz więcej panów przychodzi

29 A. Fabiś, Uczenie się osób starszych, [w:] Starzenie się i starość w perspektywie pracy socjalnej, pod. red. A. Chabior, A. Fabisia, J. K. Wawrzyniaka, Warszawa 2014, s. 79.

30 Zob. A. Fabiś, Uczenie się osób starszych, dz. cyt., s. 77.

31 Zob. Z. Szarota, Gerontologia społeczna..., dz. cyt., s. 75-76. 
na zajęcia. Klub ma szeroką ofertę: od warsztatów i spotkań przez gimnastykę po imprezy kulturalne. Dla wielu seniorów to nie tylko sposób na spędzenie czasu wolnego, ale także motywacja do wyjścia $\mathrm{z}$ domu i poruszania się. To wszystko jest bardzo ważne, szczególnie dla tych osób, które są samotne lub $z$ dala od rodziny ${ }^{32}$.

Oferta zajęć jest bardzo bogata: gimnastyka, kulturalna rozrywka, wieczorki taneczne, masaże. Ale najważniejsze, co daje takie miejsce, to kontakt z ludźmi, który jest bardzo potrzebny. „Warto w takich przedsięwzięciach brać udział właśnie ze względu na to, że nie jest się samemu"33.

Kluby seniora są ośrodkami życia kulturalnego, oświatowego, towarzyskiego i rekreacyjnego dla osób starszych. Głównym celem klubów seniora jest tworzenie warunków przyjemnego spędzania czasu wolnego i zaspokajania potrzeb wyższego rzędu (potrzeby kontaktów towarzyskich, wypoczynku, aktywności). Kluby te mają sprzyjać nawiązywaniu i podtrzymywaniu kontaktów towarzyskich, tworzeniu więzi społecznych, co w rezultacie ma przeciwdziałać uczuciu pustki, nudy i osamotnienia. Realizacji tych celów służą oferowane przez klub różnorodne zajęcia, a także współpraca klubów z innymi instytucjami i organizacjami (szkoły, domy dziecka, szpitale), która sprzyja integracji seniorów ze środowiskiem. W klubach seniora organizowane są cykliczne prelekcje, odczyty, pogadanki, kursy z zakresu różnych dziedzin wiedzy, kultury i praktyki. Organizowane są także spotkania z ciekawymi ludźmi, występy artystyczne, wieczory taneczne, wycieczki, pikniki, kuligi, zajęcia $\mathrm{z}$ tańca towarzyskiego, zabawy ruchowe. Kluby oferują gimnastykę leczniczą i zachowawczą, propagują czytelnictwo, zachęcają do brania udziału w grach stolikowych, oglądania telewizji, prowadzenia rozmów i pogadanek. Organizowane są również imprezy i uroczystości z okazji różnorakich świąt państwowych, imienin czy urodzin. Z powodu różnorodnych zainteresowań członków klubów powstają odpowiednie sekcje, np. sekcja plastyczna, wokalno-muzyczna. Członkowie mogą w klubach zasięgnąć specjalistycznych porad, poza tym pomagają sobie wzajemnie. Jest to pomoc materialna, finansowa, opiekuńcza ${ }^{34}$.

Według Izy Muchnickiej-Djakow klub seniora pełni cztery funkcje:

- kompensacyjną, czyli uzupełnia kontakty społeczne;

- psychoterapeutyczną - przeciwdziała stresowi związanemu z procesem starzenia się;

32 Zob. E. Święcicka, Senior dzisiaj zapracowany, „Echo Dnia” 46 (2015), s. 2.

33 E. Święcicka, Na emeryturę chca iść jak najpóźniej, „Echo Dnia” 46 (2015), s. 3.

34 Zob. A. Leszczyńska-Rejchert, Człowiek starszy i jego wspomaganie - w stronę pedagogiki starości, Olsztyn 2005, s. 168-170. 
- integracyjną - integruje z grupą i szerszą społecznością;

- adaptacyjną - przystosowuje do zmian w warunkach życia ${ }^{35}$.

Klub seniora to doskonałe miejsce dla ludzi nielubiących siedzieć samotnie w domu. Placówka ta doskonale wypełnia nadmiar czasu wolnego, oferując różnorodne zajęcia i szeroko rozumiane wsparcie ze strony zarówno klubu, jak i innych uczestników. Miejsce to jest bardzo potrzebne, ponieważ skutecznie przeciwdziała samotności oraz marginalizowaniu osób starszych.

\subsection{Mieszkania chronione}

Budowa mieszkań chronionych, na które jest duże zapotrzebowanie, jest bardzo opłacalną formą pomocy, ale co najważniejsze, daje szansę na prowadzenie przez najstarsze pokolenie jak najdłużej aktywnego i samodzielnego życia w środowisku, w integracji ze społecznością lokalną. Mieszkania chronione pełnią różnorodne funkcje:

- są formą świadczeń niepieniężnych pomocy społecznej, przysługujących osobom, które ze względu na trudną sytuację życiową, wiek, niepełnosprawność lub chorobę potrzebują wsparcia w funkcjonowaniu w codziennym życiu, ale nie wymagają usług w zakresie świadczonym przez jednostkę całodobowej opieki;

- zgodnie z Ustawą z dnia 12 marca 2004 r. o pomocy społecznej pobyt w mieszkaniu chronionym może być przyznany w szczególności: osobie z zaburzeniami psychicznymi, osobie opuszczającej rodzinę zastępczą, placówkę opiekuńczo-wychowawczą, młodzieżowy ośrodek wychowawczy, zakład dla nieletnich, a także cudzoziemcowi, który uzyskał w Polsce status uchodźcy lub ochronę uzupełniającą;

- są formą pomocy społecznej przygotowującą osoby tam przebywające, pod opieką specjalistów, do prowadzenia samodzielnego życia albo zastępującą pobyt w placówce zapewniającej całodobową opiekę;

- mają zapewniać warunki samodzielnego funkcjonowania w środowisku, w integracji ze społecznością lokalną;

- mogą być prowadzone przez każdą jednostkę organizacyjną pomocy społecznej lub przez organizację pożytku publicznego.

Prowadzenie i zapewnienie miejsc w mieszkaniach chronionych (co stanowi odrębne czynności) należy do zadań własnych gminy o charakterze obowiązkowym. Natomiast prowadzenie mieszkań chronionych dla osób z terenu więcej niż jednej gminy należy do zadań własnych powiatu. Przyznanie świadczenia następuje w formie decyzji administracyjnej. Decyzję administracyjną

35 Zob. A. Leszczyńska-Rejchert, Człowiek starszy..., dz. cyt., s. 170. 
o przyznaniu lub o odmowie przyznania świadczenia wydaje się po przeprowadzeniu wywiadu środowiskowego, mającego na celu ustalenie sytuacji rodzinnej, zdrowotnej, mieszkaniowej i dochodowej osoby ubiegającej się o dane świadczenie. Należy pamiętać, że pobyt w mieszkaniu chronionym ma charakter odpłatny. Opłatę za pobyt w mieszkaniu chronionym ustala podmiot kierujący w uzgodnieniu z osobą kierowaną, uwzględniając przyznany zakres usług. Osoby te nie ponoszą jednak opłat, jeżeli dochód osoby samotnie gospodarującej lub dochód na osobę w rodzinie nie przekracza kwoty kryterium dochodowego. Rada powiatu lub rada gminy w drodze uchwały ustala w zakresie zadań własnych szczegółowe zasady ponoszenia odpłatności za pobyt w mieszkaniach chronionych.

Osobami uprawnionymi do pobytu w mieszkaniach chronionych są osoby, które prowadzą jednoosobowe lub wraz z małżonkiem dwuosobowe gospodarstwo domowe, są mieszkańcami gminy, mają własne źródło utrzymania, ukończyły 60. rok życia oraz złożyły wniosek o przyznanie lokalu z zasobów miasta. Mieszkańcy mają do dyspozycji pokój z balkonem, własną kuchnię i łazienkę. W każdym z mieszkań jest dzwonek, z którego korzysta się w sytuacjach nagłych. Przez całą dobę dyżurują opiekunki, których zadaniem jest otoczenie mieszkańców troskliwą opieką, czuwanie nad ich bezpieczeństwem i zdrowiem, a także motywowanie do podejmowania różnych form aktywności, monitorowanie procesów leczenia, natychmiastowe reagowanie na wezwania alarmowe mieszkańców i interwencja w sytuacjach nagłych. Mieszkańcy otrzymują również pomoc w postaci pracy socjalnej w sprawach związanych $\mathrm{z}$ ich funkcjonowaniem $\mathrm{w}$ mieszkaniach chronionych i w środowisku, poradnictwo specjalistyczne, w szczególności prawne, psychologiczne oraz pomoc w załatwianiu spraw urzędowych i innych ważnych spraw bytowych.

\subsection{Wolontariat osób starszych}

Starość to nie tylko faza życia, w której wymaga się pomocy i wsparcia innych osób. To także czas, w którym osoby starsze mają wiele wolnego czasu, który mogą wykorzystać w ciekawy sposób. Sposobem na zagospodarowanie tego czasu może być wolontariat osób starszych. Jest to doskonały sposób aktywizacji seniorów, który daje ogromną satysfakcję i poczucie, że jest się potrzebnym.

Wolontariat to „bezpłatne, świadome i dobrowolne działanie na rzecz innych, wykraczające poza więzi rodzinno-koleżeńsko-przyjacielskie, za które wolontariusz nie otrzymuje płacy ani innej formy wynagrodzenia materialnego. Można mówić o wolontaryzmie formalnym, który jest realizowany za pośrednictwem 
organizacji społecznych, i wolontaryzmie nieformalnym, realizowanym spontanicznie przez jednostkę"36.

Wolontariuszem może być każdy, nieważne są płeć, wiek, stan majątkowy, rasa czy wykształcenie. Wszyscy chcący bezpłatnie i dobrowolnie pomagać innym mogą zostać wolontariuszami. Ludzie starsi chętnie angażują się w wolontariat. Jest to działalność samopomocowa, np. wśród grup na uniwersytecie trzeciego wieku, przy parafiach, pomoc sąsiedzka, a także samopomoc w innych organizacjach. Pomaganie tam polega najczęściej na robieniu zakupów, wyręczaniu w pracach domowych, ale również na odwiedzaniu drugiej osoby i poświęcaniu swojego czasu na rozmowę $\mathrm{z}$ nią ${ }^{37}$.

Wolontariat łączy się z ważnymi wartościami: szacunkiem dla innych, odpowiedzialnością za innych, pomocą słabszym, cierpiącym i potrzebującym wsparcia. Dla seniorów udział w wolontariacie wiąże się z możliwością wykorzystania własnego doświadczenia i ciągłego rozwoju, potrzebą bycia potrzebnym, utwierdzania więzi z rówieśnikami oraz międzypokoleniowych. Wolontariusz dzięki swojej działalności czuje sens integracji z innymi, podnosi poczucie własnej godności, wartości, a przede wszystkim czuje satysfakcję z życia. Badania realizowane $\mathrm{z}$ tym obszarze pokazują, że wolontariat wpływa na:

- większy dobrostan psychologiczny, czyli większy poziom satysfakcji z życia, zadowolenie z siebie, swoich działań, mniejszy poziom lęku i co za tym idzie stresu;

- wzrost długości życia;

- większe zaangażowanie społeczne i przystosowanie do różnych warunków życia;

- lepsze zdrowie fizyczne i odporność immunologiczną;

- mniejszy poziom depresji, poczucia beznadziejności i stresu ${ }^{38}$.

Bardzo ważny jest fakt, że wiele osób starszych znajduje się w trudnej sytuacji, potrzebując różnego rodzaju wsparcia. Wolontariat podejmowany bezinteresownie w imię miłości do drugiego człowieka może zaspokoić potrzeby seniorów. Ze względu na utrudnione kontakty ze światem zewnętrznym, a także brak miejsca dla ludzi mniej sprawnych, pojawia się zjawisko wycofywania seniorów z życia społecznego. Największym problemem społecznym osób starszych jest samotność. Natomiast wolontariat może to zmienić, pomagając przezwyciężyć samotność, zapominać o niej. Wolontariat daje możliwości dalszego rozwoju,

36 B. Szatur-Jaworska, P. Błędowski, M. Dzięgielewska, Podstawy gerontologii społecznej, Warszawa 2006, s. 177.

37 Zob. B. Szatur-Jaworska, P. Błędowski, M. Dzięgielewska, Podstawy gerontologii społecznej, dz. cyt., s. 178.

38 Zob. S. Steuden, Psychologia starzenia się i starości, Warszawa 2011, s. 98-99. 
pomaga odkrywać swoje zainteresowania i uzdolnienia, ale również pozwala realizować pragnienia sprzed wielu lat. Aktywność w wolontariacie, stowarzyszeniach i pracach społecznych staje się dla wielu seniorów stylem życia, który jest bardzo ważny i wartościowy. Starszych wolontariuszy można spotkać w bardzo różnych miejscach: szpitalach, hospicjach, domach opieki społecznej. Pomagają oni innym robić zakupy, czytają książki, chodzą na spacery. Seniorzy angażują się również w pomoc dzieciom w odrabianiu lekcji i organizacji czasu wolnego ${ }^{39}$.

Wolontariat to tylko jeden ze sposób aktywizacji seniorów. Działania te nie wymagają wielkich nakładów finansowych, co jest niewątpliwie ich ogromną zaletą. Wystarczy do tego tylko chęć niesienia pomocy i dobra wola, a można osiągnąć bardzo wiele, pomagając zarówno sobie, jak i innym. Wystarczy rozejrzeć się wokół siebie, a na pewno znajdzie się ktoś, kto potrzebuje naszego wsparcia i pomocy. Należy pamiętać, że pomaganie wcale nie musi wiązać się $\mathrm{z}$ wydawaniem własnych pieniędzy. Większe znaczenie dla drugiego człowieka ma poświęcenie mu czasu na rozmowę, spacer czy pomoc w pracach domowych. Aktywność, nawet w starszym wieku, jest bardzo istotna, daje chęć do życia i pozwala pokonywać szarą rzeczywistość. Powstawanie coraz to nowych instytucji wspierających seniorów jest najlepszym dowodem na to, jak ważne jest podtrzymywanie i rozwijanie zainteresowań oraz pasji, a także jak wielkie jest na to zapotrzebowanie. Stwarzanie możliwości ciekawego spędzania czasu wolnego daje starszym ludziom poczucie bycia potrzebnym i akceptowanym społecznie. Szeroka oferta tych instytucji pozwala każdemu znaleźć coś dla siebie i cieszyć się życiem, na ile pozwala zdrowie.

\section{Podsumowanie}

Starość dotyczy każdego człowieka, trudno znaleźć kogoś, kto nigdy nie zetknął się z tym zjawiskiem. Większość społeczeństwa myśli o tej fazie życia bardzo stereotypowo, dla wielu słowa „starość" $i$,starzenie się" oznaczają tylko i wyłącznie cierpienie i smutek. Dlatego w tej sprawie bardzo ważna okazuje się rola władz poszczególnych państw w przełamywaniu tego stereotypu. Należy uświadamiać i ukazywać seniorom, jak mogą zmienić swoje codzienne życie poprzez aktywne uczestniczenie w życiu społecznym i otwarcie się na różnego rodzaje propozycje ze strony poszczególnych społeczności. Ze postępującym procesem starzenia się społeczeństw boryka się nie tylko Polska, ale również wiele krajów Europy. Jest to niekorzystna sytuacja, która ma wielorakie przyczyny. Wśród nich można

39 Zob. M. Dzięgielewska, Wolontariat osób starszych, [w:] Starzenie się a satysfakcja $z \dot{z} y c i a$, pod red. S. Steuden, Lublin 2006, s. 267-268. 
wyróżnić spadek liczby urodzeń, wzrost długości życia, emigrację zarobkową, wydłużenie się okresu kształcenia młodych ludzi, niskie wynagrodzenia, które powodują odkładanie decyzji o założeniu rodziny, jak również „modę” na bycie singlem. Starzejące się społeczeństwa to bardzo duży problem dla wielu krajów Europy, który niesie za sobą bardzo poważne konsekwencje oraz wymaga natychmiastowych i stanowczych kroków. Koszty, które muszą ponosić poszczególne państwa, to zwiększanie nakładów finansowych nie tylko na emerytury i renty, ale również na usługi zdrowotne i opiekuńcze. Pojawia się także potrzeba organizacji życia seniorów poprzez tworzenie placówek wspierających. Niestety wszystko to dzieje się kosztem innych grup społecznych, na których potrzeby często brakuje pieniędzy. Jeżeli tendencja ta się nie odwróci, skutki tego procesu będą katastrofalne i niełatwe do pokonania dla kolejnych pokoleń.

\section{Bibliografia}

Balon K. i in., Preambuła i pakiet usług pomocy i integracji społecznej dla osób starszych, Projekt 1.18 „Tworzenie i rozwijanie standardów usług pomocy i integracji społecznej” współfinansowany ze środków Unii Europejskiej w ramach Europejskiego Funduszu Społecznego, Warszawa 2014.

Raport na temat sytuacji osób starszych w Polsce, oprac. P. Błędowski i in., Warszawa 2012.

Departament tematyczny. Spójność społeczna i rozwój demograficzny w zrównoważonej Europie, Parlament Europejski, Bruksela 2011.

Dzięgielewska M., Wolontariat osób starszych, [w:] Starzenie się a satysfakcja z życia, pod red. S. Steuden, Lublin 2006, s. 267-268.

Gabiś T., Od Unii Europejskiej do Imperium Europejskiego, [w:] Tożsamość Starego Kontynentu i przyszłość projektu europejskiego, pod red. D. Pietrzyk-Reeves, Warszawa 2007, s. 241-256.

Fabiś A., Uczenie się osób starszych, [w:] Starzenie się i starość w perspektywie pracy socjalnej, pod red. A. Chabior, A. Fabisia, K. Wawrzyniaka, Warszawa 2014, s. 76-80.

Halicki J., Edukacja seniorów w aspekcie teorii kompetencyjnej. Studium historyczno-porównawcze, Białystok 2000.

Henzler M., Więcej dziadków niż wnuków,„Polityka” 49/2002, s. 20-22.

Jachimowicz D., Nalepa W., Tworzenie Uniwersytetu Trzeciego Wieku - krok po kroku, Nowy Sącz 2012.

Jan Paweł II, List Do moich braci i sióstr - ludzi w podeszłym wieku.

Jastrzębski, Psychologiczny wymiar lęku przed śmiercia, www.psychologia.net.pl (dostęp: 20.02.2016).

Kurowska K., Aktywizacja osób w starszym wieku w aspekcie działalności Uniwersytetów Trzeciego Wieku oraz innych instytucji i organizacji pozarzadowych, [w:] Kompendium 
pielegnowania pacjentów w starszym wieku, pod red. K. Kędziory-Kornatowskiej, M. Muszalik, Lublin 2007, s. 49-56.

Matalkiewicz A., Edukacja seniorów w Wielkiej Brytanii - Uniwersytet Trzeciego Wieku, „Edukacja Dorosłych” 2/2003, s. 121-135.

Leszczyńska-Rejchert A., Człowiek starszy i jego wspomaganie - w stronępedagogiki starości, Olsztyn 2005.

Obsesyjny lęk przed śmiercia, www.netkobiety.pl (dostęp: 20.02.2016).

Oramus M., Pietkiewicz B., Siwe włosy ludzkości,„Polityka” 20/2001, s. 3-9.

Paniczny lęk przed śmiercia, www.psychiatria.pl (dostęp: 20.02.2016).

Paniczny strach przed śmiercią a nerwica, www. forum.kardiolo.pl (dostęp: 20.02.2016).

Plitta W., Polityka społeczna Unii Europejskiej wobec osób starszych, „Pracownik Socjalny” 10/2006, s. 6-9.

Porąbaniec M., Instytucjonalny wymiar pracy socjalnej na rzecz osób starszych w środowisku lokalnym, [w:] Człowiek stary w rodzinie i społeczeństwie, red. A. Kotlarska-Michalska, Poznań 2013, s. 187-207.

Rotkiewicz M., Jesień świata,,Polityka” 20/2002, s. 76-77.

Steuden S., Psychologia starzenia się i starości, Warszawa 2011.

Święcicka E., Senior dzisiaj zapracowany, „Echo Dnia” 46/2015, s. 2.

Święcicka E., Na emeryturę chca iść jak najpóźniej, „Echo Dnia” 46/2015, s. 3.

Syndrom pustego gniazda- jak sobie $z$ nim radzić?, www.poradnikzdrowie.pl (dostęp: 20.02.2016).

Szatur-Jaworska B., Sytuacja rodzinna i więzi rodzinne ludzi starych i osób na przedpolu starości, [w:] Aspekty medyczne, psychologiczne, socjologiczne i ekonomiczne starzenia się ludzi w Polsce, pod red. M. Mossakowskiej, A. Więcek, P. Błędowskiego, Poznań 2002, s. 449-467.

Szatur-Jaworska B., Błędowski P., Dzięgielewska M., Podstawy gerontologii społecznej, Warszawa 2006.

Sztaudynger J. [w:] Z. Szarota, Gerontologia społeczna i oświatowa. Zarys problematyki, Kraków 2004, s. 43.

Sztajer Z., Idea powstania i działalność uniwersytetów trzeciego wieku, www.edukator.koweziu. edu.pl/176/ (dostęp: 19.11.2015).

Szukalski P., Starzenie się ludności - wyzwanie XXI wieku, [w:] Przygotowanie do starości. Polacy wobec starzenia się, pod red. P. Szukalskiego, Warszawa 2009, s. 7-26.

Ubezpieczenie pielegnacyjne jako propozycja rozwiazań, www.czytelniamedyczna.pl (dostęp: 20.02.2015).

Ustawa z dnia 14 marca 2004 r. o pomocy społecznej, Dz.U. 2004 nr 64 poz. 593.

Zdaniewicz M., Gerontologia jako potrzeba specjalistycznego kształcenia pracowników socjalnych, [w:] Instytucje pomocy w służbie ludziom, pod red. Z. Wołka, Zielona Góra 2003, s. 183-191. 